\title{
PROSES INTERAKSI KOMUNIKASI SISWA SMP DALAM DISKUSI KELOMPOK MATERI PERSAMAAN GARIS LURUS DITINJAU DARI JENIS KELAMIN
}

\author{
Moh. Syukron Maftuh \\ Program Studi Pendidikan Matematika FKIP UNIPA Surabaya \\ Jl. Ngagel Dadi III-B/37di Surabaya, syukron@unipasby.ac.id
}

\begin{abstract}
ABSTRAK
Penelitihan ini bertujuan untuk mendeskripsikan proses interaksi komunikasi siswa perempuan maupun laki-laki dalam diskusi kelompok pada materi persamaan garis lurus. Penelitihan ini dilaksanakan di SMP Negeri 1 Driyorejo dengan subjek penelitihan terdiri dari dua kelompok diskusi yaitu kelompok perempuan dan kelompok laki-laki, dimana masing-masing kelompok terdiri dari tiga siswa kelas VIII. Penelitian ini merupakan penelitian deskriptif dengan pendekatan kualitatif. Terdapat tiga tahap dalam pengambilan data dalam penelitihan ini. Pertama, peneliti melakukan wawancara dengan subjek sebelum pembelajaran berlangsung. Kedua, peneliti merekam pembicaraan yang dilakukan oleh subjek saat diskusi kelompok berlangsung. Terakhir, peneliti melakukan wawancara dengan sebjek setelah pembelajaran berlangsung. Pengecekan keabsahan data menggunakan triangulasi waktu. Dan adapun hasil penelitihan menunjukkan bahwa: (1) proses interaksi komunikasi yang terjadi pada kelompok perempuan merupakan interaksi yang aktif. Semua subjek saling berinteraksi dalam menyelesaikan masalah yang ada pada LKS. (2) proses interaksi komunikasi yang terjadi pada kelompok laki-laki dikatakan interaksi pasif. Hal ini dikarenakan tidak semua subjek laki-laki saling berinteraksi dalam menyelesaikan permasalahan yang ada pada LKS.
\end{abstract}

Kata Kunci : Proses interaksi komunikasi, diskusi kelompok materi persamaan garis lurus, jenis kelamin.

\begin{abstract}
This research aims to describe the process of communication interaction within group discussion based on gender in Mathematics' study particularly straight-line equations. The research was carried out at $8^{\text {th }}$ grade in SMP Negeri 1 Driyorejo The research involves two kind of subject namely the women's group and the men's group which each group consisted of three students and is a descriptive study with a qualitative approach. There are three stages in collecting students' data: interview before the class started, record each conversation during the group discussion, and interview after the learning process. In terms of validity of the research, those data are checked using time triangulation. The results show that women's group are more active during discussion compare with man's group. While all member in women's group communicated actively in solving problem, some of men's member contributed in solving problem in worksheet
\end{abstract}

Keywords : Communication interaction process, gender, group discussion of straight-line equation material.

\section{PENDAHULUAN}

$$
\text { Pendidikan merupakan hal }
$$

terpenting dalam kemajuan suatu Negara.

Suatu Negara dikatakan maju apabila dapat

mencetak sumber daya manusia yang berkualitas baik dari segi spiritual, intelegensi, dan skil. Sebagaimana tercantum dalam UU No. 20 Tahun 2003, pendidikan adalah usaha sadar dan terencana untuk mewujudkan suasana belajar dan proses pembelajaran agar peserta 
didik secara aktif mengembangkan potensi dirinya untuk memiliki kekuatan spiritual keagamaan, pengendalian diri, kepribadian, kecerdasan, akhlak mulia, serta keteramilan yang diperlukan dirinya, masyarakat, bangsa dan Negara.

Salah satu penunjang dalam menciptakan sumber daya manusia yang berkualitas adalah dengan pendidikan matematika. Pendidikan matematika merupakan salah satu bagian dari pendidikan, sehingga matematika merupakan aspek penting kehidupan dalam membentuk dan membina manusia yang berkualitas. Sebagaimana yang tercantum dalam kurikulum 2006, matematika merupakan ilmu universal yang mendasari perkembangan teknologi modern, memiliki peran penting dalam berbagai disiplin ilmu dan memajukan daya pikir manusia. Oleh karena itu, sangat penting bagi setiap manusia untuk belajar matematika. Mata pelajaran matematika merupakan mata pelajaran yang diajarkan pada setiap jenjang pendidikan, dimulai dari pendidikan dasar hingga pendidikan menengah atas. Namun pada kenyataannya, masih banyak siswa yang tidak menyukai matematika. Hal ini disebabkan karena matematika merupakan objek kajian yang bersifat abstrak dan memerlukan penalaran yang tinggi dalam menentukan sebuah konsep sehingga dalam mengajar matematika guru harus mampu memberikan penjelasan dengan baik agar konsep-konsep matematika yang abstrak dapat dipahami siswa

Menurut Soedjadi (dalam Tri Yanuar, 2016:1), guru dalam melaksanakan pembelajaran di sekolah diharapkan dapat berusaha untuk mengurangi sifat abstrak dalam pembelajaran matematika, karena Dalam belajar matematika, siswa diharapkan dapat menentukan bentuk konsep yang dibangun. Konsep yang dibangun dalam matematika pada umumnya disusun dari konsep-konsep sebelumnya. Misalnya diambil contoh dalam pembelajaran materi persamaan garis lurus, untuk mempelajari persamaan garis lurus diperlukan pemahaman siswa tentang materi prasyarat, seperti memahami materi persamaan linear satu variabel, memahami materi tentang fungsi, kemudian memahami materi koordinat kartesius. Materi-materi prasyarat tersebut yang selanjutnya akan memudahkan siswa dalam membentuk konsep persamaan garis lurus. Apabila konsep yang dibangun siswa telah sesuai dengan materi yang dipelajari maka tujuan pembelajaran telah tercapai.

Ketika menentukan sebuah konsep yang akan dibangun, itu bisa muncul pada saat siswa akan berdiskusi dengan teman sebaya, karena disitu siswa akan menyampaikan tentang pendapatpendapatnya. Sehingg terjadi proses interaksi komunikasi. Proses interaksi bisa dilakukan antara siswa dengan guru, siswa 
dengan siswa dan siswa dengan sumber belajar pada suatu lingkungan belajar, sehingga diperlukan komunikasi yang jelas antara siswa dengan guru, siswa dengan siswa, dan siswa dengan sumber belajar agar tujuan pembelajaran tercapai. Proses interaksi komunikasi ini dapat dilakukan dengan diskusi kelompok. Dimana setiap anggota dapat berkesempatan untuk menyampaikan ide-ide maupun pendapatnya selama proses pembelajaran. Pada saat siswa berinteraksi untuk menyampaikan pendapat-pendapatnya secara otomatis siswa akan menentukan bentuk skema yang dibangun. Jika skema yang dibentuk memiliki tingkat keterhubungan yang erat, maka skema itu menjadi skema yang kompleks. Proses interaksi komunikasi yang dimaksudkan dalam penelitian ini adalah interaksi antar setiap individu dalam diskusi kelompok untuk menyelesaikan suatu permasalahan yang ada dalam LKS. Dalam interaksi ini setiap siswa akan dibagi menjadi beberapa kelompok berdasarkan jenis kelaminnya. Setipa anggota kelompok akan memberikan ide atau pengetahuan yang telah dimiliki kepada anggota lain, begitupun sebaliknya

Terdapat berbagai macam komunikasi, salah satu diantaranya adalah komunikasi verbal dan komunikasi non verbal. Agus M. Hardjana (dalam Paramitha, 2016:26) berpendapat bahwa komunikasi verbal adalah komunikasi yang menggunakan kata-kata, entah lisan maupun tulisan. Sedangkan komunikasi non verbal menurut Julia T. Wood (dalam Paramitha, 2016:27) adalah semua aspek komunikasi selain kata-kata. Komunikasi non verbal dapat berupa bahasa tubuh, tanda, tindakan, perbuatan, atau objek. Pada penelitian ini teori komunikasi yang digunakan dalam penelitihan ini adalah teori komunikasi Laswell dimana terdapat 5 formula komunikasi untuk terjadinya proses komunikasi, yaitu siapa (who) - berbicara apa (says what) - dengan media apa (in which channel) - kepada siapa (to whom) dan dengan efek apa (with what effect)

Setiap individu memiliki cara yang berbeda-beda dalam berinteraksi, terutama jika dilihat berdasarkan perbedaan jenis kelamin. Menurut Sukmadinata (dalam Riyadi dkk, 2013:159) perempuan dan lakilaki secara kodrat berbeda, keduanya memiliki ciri-ciri yang berbeda, dalam halhal tertentu kemampuan keduannya juga berbeda. Adanya perbedaan ciri-ciri yang dimiliki antara siswa, sehingga laki-laki dan perempuan tentunya mempengaruhi proses interaksi komunikasi siswa dalam berdiskusi. Berdasarkan pemaparan di atas, sehingga peneliti tertarik untuk melakukan penelitihan dengan judul "Proses Interaksi Komunikasi Siswa SMP dalam Diskusi Kelompok Materi Persamaan Garis Lurus Ditinjau dari Jenis Kelamin" 


\section{METODE PENELITIAN}

Penelitian ini termasuk dalam penelitian deskriptif kualitatif. Pada penelitihan ini peneliti berusaha untuk mendeskripsikan proses interaksi komunikasi siswa kelas VIII SMP Negeri 1 Driyorejo dalam suatu diskusi kelompok pada materi persamaan garis lurus. Penelitian ini dilakukan tidak mengolah data berupa angka, melainkan mengolah data dari hasil wawancara terhadap siswa terpilih yang menjadi subjek penelitihan sebelum pembelajaran, data hasil rekaman pembicaraan siswa pada saat pembelajaran, dan data hasil wawancara terhadap siswa terpilih yang menjadi subjek penelitihan setelah dilakukan pembelajaran. Sumber data pada penelitihan ini adalah dua kelompok diskusi yaitu kelompok pertama terdiri dari 3 siswa perempuan yang selanjutnya disebut subjek SP1, SP2, dan SP3. Kemudian kelompok ke dua terdiri dari 3 siswa laki-laki yang selanjutnya disebut subjek SL1, SL2, dan SL3

\section{HASIL DAN PEMBAHASAN}

Hasil penelittihan dikelompokkan menjadi 5 pertemuan. Pertemuan pertama diperoleh dari data mengenai proses interaksi komunikasi siswa pada LKS 1, pertemuan kedua diperoleh dari data mengenai proses interaksi komunikasi siswa pada LKS 2, pertemuan ketiga diperoleh dari data mengenai proses interaksi komunikasi siswa pada LKS 3, pertemuan ke empat diperoleh dari data mengenai proses interaksi komunikasi siswa pada LKS 4, dan pertemuan ke lima diperoleh dari data mengenai proses interaksi komunikasi siswa pada LKS 5. Masing-masing pertemuan menunjukkan proses interaksi antar siswa dan interaksi dengan LKS. Dalam interaksi antar siswa terjadi penyampaian gagasan, saling memberikan komentar, saling bertanya apabila ada hal yang belum dimengerti.

\section{Subjek Perempuan}

Pada pertemuan pertama SP1 merupakan siswa yang aktif. Dia lebih banyak berinteraksi dan menjawab pertanyaan yang ada di LKS. SP1 lebih banyak berinteraksi dengan temannya. Disamping itu SP2 juga merupakan siswa yang aktif. Dia juga banyak berinteraksi dan menjawab pertanyaan yang ada di LKS Sedangkan untuk SP3, SP3 merupakan siswa yang cukup aktif. SP3 cukup berinteraksi dengan temannya. Dalam pertemuan ini, subjek penelitihan melakukan diskusi dengan aktif, mereka saling bekerja sama untuk menyelesaikan permasalahan yang ada pada LKS

Dalam pembelajaran pada pertemuan kedua, SP1 merupakan siswa yang aktif. Dia lebih banyak berinteraksi dan menjawab pertanyaan yang ada di LKS. Pada materi gradient garis lurus dan menentukan gradient garis lurus ini SP1 lebih banyak 
berinteraksi dengan temannya. SP1 berinteraksi dengan SP2 dan SP3 untuk menarik kesimpulan bahwa gradient itu sisi tegak dibagi sisi mendatar. Selain itu SP2 juga merupakan siswa yang aktif. Dia berinteraksi dan menjawab pertanyaan yang ada di LKS. SP2 berinteraksi dengan SP1 dan SP3 untuk menarik kesimpulan bahwa gradient itu sisi tegak dibagi sisi mendatar. Sedangkan SP3 disini juga merupakan siswa yang aktif. Dia berinteraksi dan menjawab pertanyaan yang ada di LKS. SP3 berinteraksi dengan SP1 dan SP2 untuk menarik kesimpulan bahwa gradient sisi tegak dibagi sisi mendatar.

Dalam pembelajaran pada pertemuan ke tiga, SP1 merupakan siswa yang aktif. Dia lebih banyak berinteraksi dan menjawab pertanyaan yang ada di LKS. Pada materi gradient gars sejajar dan tegak lurus ini SP1 lebih banyak berinteraksi dengan temannya. SP1 berinteraksi dengan SP2 dan SP3 untuk menarik kesimpulan bahwa gradient garis sejajar itu sama. Sedangkan SP2 merupakan siswa yang aktif. Dia berinteraksi dan menjawab pertanyaan yang ada di LKS. SP2 berinteraksi dengan SP1 dan SP3 untuk menarik kesimpulan bahwa bahwa gradient garis sejajar itu sama. Untuk SP3, SP3 juga merupakan siswa yang cukup aktif. Dia berinteraksi dan menjawab pertanyaan yang ada di LKS. SP3 berinteraksi dengan SP1 dan SP2 untuk menarik kesimpulan bahwa gradient garis sejajar itu sama
Dalam pembelajaran pada pertemuan ke empat, SP1 merupakan siswa yang aktif. Dia lebih banyak berinteraksi dan menjawab pertanyaan yang ada di LKS. Pada materi menentukan persamaan garis lurus jika diketahui gradiennya dan satu titik ini SP1 lebih banyak berinteraksi dengan temannya. Selanjutnya untuk SP2, SP2 merupakan siswa yang aktif. Dia berinteraksi dan menjawab pertanyaan yang ada di LKS. Pada materi menentukan persamaan garis lurus jika diketahui gradiennya dan satu titik ini, sedangkan SP3 merupakan siswa yang cukup aktif. Dia berinteraksi dan menjawab pertanyaan yang ada di LKS. Pada materi menentukan persamaan garis lurus jika diketahui gradiennya dan satu titik ini SP3 berinteraksi dengan SP1 dan SP2 untuk menarik kesimpulan bagaimana rumus menentukan persamaan garis lurus jika diketahui gradiennya dan satu titik.

Dalam pembelajaran pada pertemuan V, SP1 merupakan siswa yang aktif. Dia lebih banyak berinteraksi dan menjawab pertanyaan yang ada di LKS. Pada materi menentukan persamaan garis lurus jika melalui dua titik SP1 lebih banyak berinteraksi dengan temannya. SP1 berinteraksi dengan SP2 dan SP3 untuk menarik kesimpulan bagaimana rumus menentukan persamaan garis lurus yang melalui dua titik. Selain itu, Dalam pembelajaran pada pertemuan $\mathrm{V}, \quad \mathrm{SP} 2$ merupakan siswa yang aktif. Pada materi 
menentukan persamaan garis lurus jika melalui dua titik. Disamping itu, SP3 merupakan siswa yang cukup aktif. Pada materi menentukan persamaan garis lurus jika diketahui dua titik yang dilalui. SP3 berinteraksi dengan SP1 dan SP3 untuk menarik kesimpulan bagaimana rumus menentukan persamaan garis lurus yang melalui dua titik.

Berikut ini disajikan gambar proses interaksi siswa perempuan saat diskusi kelompok berlangsung pada pertemuan kesatu, kedua, ketiga, keempat dan kelima pada Gambar 1 hingga Gambar 5.

\section{Subjek Laki-laki}

Pada pertemuan pertama SL1 merupakan siswa yang aktif. Dia lebih banyak berinteraksi dan menjawab pertanyaan yang ada di LKS. Pada materi menggambar garis lurus ini SL1 lebih banyak berinteraksi dengan temannya. SLI berinteraksi dengan SL2 dan SL3 tentang cara menggambar grafik garis lurus dengan dua titik sebarang. SL2 juga merupakan siswa yang aktif. Dia banyak berinteraksi dan menjawab pertanyaan yang ada di LKS. Sedangkan SL3 merupakan siswa yang pasif. SL3 hanya menerima pengetahuan dari temannya, SL3 cenderung mendengarkan temanya berdiskusi

Dalam pembelajaran pada pertemuan kedua, SL1 merupakan siswa yang aktif. Dia lebih banyak berinteraksi dan menjawab pertanyaan yang ada di LKS. SL2 merupakan siswa yang cukup aktif. Pada materi gradient garis lurus dan menentukan gradient garis lurus ini SL2 berinteraksi dengan temannya. Dan SL3 merupakan siswa yang pasif. SL3 hanya menerima pengetahuan dari temannya.

Dalam pembelajaran pada pertemuan ketiga, SL1 merupakan siswa yang aktif. Dia lebih banyak berinteraksi dan menjawab pertanyaan yang ada di LKS. Pada materi gradient garis sejajar dan tegak lurus ini SL1 lebih banyak berinteraksi dengan temannya. SL2 merupakan siswa yang cukup aktif. Pada materi gradient garis sejajar dan tegak lurus ini SL2 berinteraksi dengan temannya. SL2 berinteraksi dengan SL1 dan SL3 untuk menarik kesimpulan bahwa gradient garis sejajar adalah sama. Sedangkan SL3 merupakan siswa yang pasif. SL3 hanya menerima pengetahuan dari temannya, SL3 cenderung mendengarkan temanya berdiskusi kemudian membantu hal-hal kecil seperti menghitung.

Dalam pembelajaran pada pertemuan ke empat, SL1 merupakan siswa yang aktif. Dia lebih banyak berinteraksi dan menjawab pertanyaan yang ada di LKS. Pada materi menentukan persamaan garis lurus jika diketahui gradiennya dan satu titik ini SL1 lebih banyak berinteraksi dengan temannya. SL1 berinteraksi dengan SL2 dan SL3 untuk menarik kesimpulan bagaimana rumus menentukan persamaan garis lurus jika 
diketahui gradiennya dan satu titik SL2 merupakan siswa yang aktif. Pada materi menentukan persamaan garis lurus jika diketahui gradiennya dan satu titik. SL3 merupakan siswa yang pasif. SL3 hanya menerima pengetahuan dari temannya, SL3 cenderung mendengarkan temanya.

Dalam pembelajaran pada pertemuan V, SL1 merupakan siswa yang aktif. Dia lebih banyak berinteraksi dan menjawab pertanyaan yang ada di LKS. Pada materi menentukan persamaan garis lurus jika diketahui dua titik yang dilalui ini SL1 lebih banyak berinteraksi dengan temannya. SL2 merupakan siswa yang aktif. Pada materi menentukan persamaan garis lurus jika dua titik ini SL2 berinteraksi dengan SL1 dan SL3 untuk menarik kesimpulan bagaimana rumus menentukan persamaan garis lurus yang melalui dua titik. Sedangkan SL3 merupakan siswa yang pasif. SL3 hanya menerima pengetahuan dari temannya, SL3 cenderung mendengarkan temanya berdiskusi kemudian membantu hal-hal kecil seperti menghitung. Pada pertemuan yang membahas tentang menentukan persamaan garis lurus jika diketahui gradiennya dan satu titik, SL3 menerima pengetahuan dari SL1 dan SL2 tentang beberapa hal yang belum dimengerti.

Berikut ini adalah gambar proses interaksi siswa laki-laki saat diskusi kelompok berlangsung pada pertemuan kesatu, kedua, ketiga, keempat, dan kelima pada Gambar 6 sampai Gambar 10.

Dari gambar-gambar tersebut dapat dilihat proses interaksi siswa perempuan maupun siswa laki-laki saat diskusi berlangsung. Garis dengan kedua ujung bertanda panah menunjukkan bahwa terjadi interaksi diantara keduanya. Garis dengan pangkal dan satu tanda panah menunjukkan bahwa terjadi proses pemberian informasi dari pangkal ke ujung panah. Garis putusputus berwarna merah menunjukkan hal-hal yang belum diketahui oleh masing-masing siswa.

Dari hasil interaksi tersebut, dapat ditunjukkan bahwa proses interaksi siswa SMP dalam diskusi kelompok materi persamaan garis lurus ditinjau dari jenis kelamin: (1) Proses interaksi komunikasi siswa perempuan. Proses interaksi komunikasi yang terjadi pada kelompok perempuan merupakan interaksi yang aktif. Semua subjek saling berinteraksi. SP1 dan SP2 sebagai siswa yang memahami materi sebelum pembelajaran saling berinteraksi dalam diskusi. Sedangkan SP3 sebagai siswa yang kurang memahami materi sebelum pembelajaran, SP3 tetap aktif dalam berdiskusi. SPI, SP2, dan SP3 saling berinteraksi dalam mengkonstruksi konsep yang ada pada LKS. Terlihat bahwa interaksi yang terjadi sesuai dengan pendapat Maccoby dan Jacklyn (dalam Nafi'an, 2013) yang mengatakan perempuan 
mempunyai kemampuan verbal yang tinggi.

Hal ini dikarenakan perempuan memiliki verbal center pada kedua bagian otaknya.

(2) Proses interaksi Komunikasi siswa lakilaki. Proses interaksi komunikasi yang terjadi pada kelompok laki-laki dikatakan interaksi pasif. Hal ini dikarenakan tidak semua subjek laki-laki saling berinteraksi. Saat pembelajaran berlangsung hanya SL1 dan SL2 yang saling berinteraksi dan bertukar pikiran. SL3 sebagai siswa yang kurang memahami materi sebelum pembelajaran hanya mendengarkan temannya berdiskusi. SL3 hanya menunggu jawaban dari temannya. Hal ini juga sesuai dengan pendapat Maccoby dan Jacklyn (dalam Nafi'an, 2013) yang mengatakan bahwa laki-laki memiliki kemamuan verbal yang kurang. Hal ini dikarenakan laki-laki hanya memiliki verbal center pada otak bagian kiri.

Selain itu proses interaksi komunikasi juga terjadi dari siswa yang memahami materi sebelum pembelajaran kepada siswa yang kurang memahami materi sebelum pembelajaran. Dengan kata lain proses interaksi berpikir tersebut terjadi dari siswa yang berkemampuan tinggi kepada siswa berkemampuan rendah. Hal ini sesuai dengan penelitian yang dilakukan oleh Nur'aini dan Subanji (2013) yang menyebutkan bahwa terjadinya proses interaksi berpikir pada saat belajar kelompok, berlangsung secara multiarah.
Dengan demikian diskusi kelompok sangat berpengaruh terhadap masing-masing subjek dalam menyelesaikan permasalahann yang ada pada LKS tentang materi persamaaan garis lurus.

\section{KESIMPULAN DAN SARAN}

Berdasarkan analisis data dan pembahasan yang telah diuraikan, dapat diambil kesimpulan bahwa proses interaksi komunikasi selama pembelajaran berlangsung terjadi secara multiarah, yaitu dari siswa yang memahami materi sebelum pembelajaran kepada siswa yang kurang memahami materi sebelum pembelajaran. Selain itu, terdapat perbedaan interaksi yang terjadi saat pembelajaran berlangsung antara kelompok perempuan dan kelompok lakilaki.

Proses interaksi Komunikasi siswa perempuan. Proses interaksi komunikasi yang terjadi pada kelompok perempuan merupakan interaksi yang aktif. Semua subjek saling berinteraksi untuk mengerjakan permasalahan yang ada dalam LKS. SP1 dan SP2 sebagai siswa yang memahami materi sebelum pembelajaran saling berinteraksi dalam diskusi. Sedangkan SP3 sebagai siswa yang kurang memahami materi sebelum pembelajaran, SP3 tetap aktif dalam berdiskusi. SPI, SP2, dan SP3 saling berinteraksi dalam mengkonstruksi konsep yang ada pada LKS. 
Proses interaksi Komunikasi siswa laki-laki. Proses interaksi komunikasi yang terjadi pada kelompok laki-laki dikatakan interaksi pasif. Hal ini dikarenakan tidak semua subjek laki-laki saling berinteraksi dalam mengerjakan permasalahan yang ada dalam LKS. Saat pembelajaran berlangsung hanya SL1 dan SL2 yang saling berinteraksi dan bertukar pikiran. SL3 sebagai siswa yang kurang memahami materi sebelum pembelajaran hanya mendengarkan temannya berdiskusi. SL3 hanya menunggu jawaban dari temannya.

Berdasarkan hasil penelitian yang telah diuraikan, saran dalam penelitian ini adalah sebagai berikut: (1) Dalam membentuk suatu kelompok belajar, guru harus memperhatikan kemampuan siswa. Guru hendaknya membentuk kelompok tersendiri bagi siswa yang kemampuannya kurang. Hal ini dimaksudkan agar guru bisa memberikan perhatian lebih dalam membantu siswa membentuk pengetahuan sehingga tujuan pembelajaran tercapai. (2) Guru hendaknya selalu mendorong siswa agar aktif dalam diskusi kelompok. (3) Perlu dilakukan penelitian lanjutan terhadap penelitian ini sehingga dapat diperoleh hasil yang optimal.

\section{DAFTAR PUSTAKA}

Depdiknas. 2006. Kurikulum tingkat satuan pendidikan (KTSP). Jakarta: Departemen Pendidikan Nasional.
Nafi'an, Muhammad. 2013. “Kemampuan siswa dalam menyelesaikan soal cerita ditinjau dari gender di sekolah dasar". Prosiding ISBN: 978-979-16353-6-3, P-53.

Paramitha, D. 2016. Fenomena perilaku remaja boreken home di SMA BPI Bandung. Skripsi Universitas Pasundan.

Riyadi, Sandie., dan Budi Usodo. 2013. "Proses berpikir siswa tunagrahita dalam pemecahan masalah matematika ditinjau dari perbedaan gender." Dalam Jurnal Pendidikan Informatika dan Sains, Vol. 2, No. 2.

Sukmadinata, Nana Syaodih. 2011. Landasan psikologi proses pendidikan. Bandung: Remaja Rosdakarya.

Tri, Yanuar Rahimawati. 2016. Analisis proses berpikir dalam pemecahan masalah matematika polya siswa kelas XI SMAN 1 Bangsri Jepara berdasarkan tipe kepribadian. Skripsi. Universitas Islam Negeri Walisongo Semarang. 


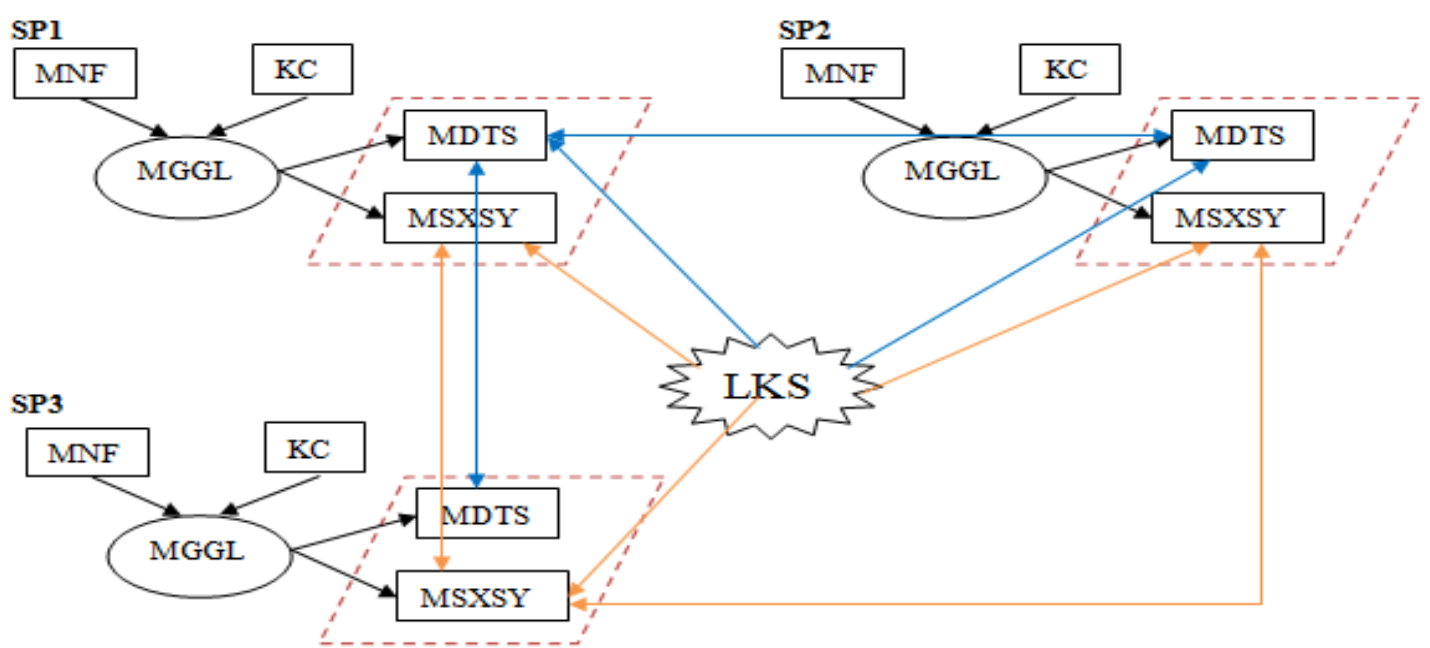

Gambar 1. Proses interaksi siswa perempuan saat diskusi kelompok berlangsung pada pertemuan pertama

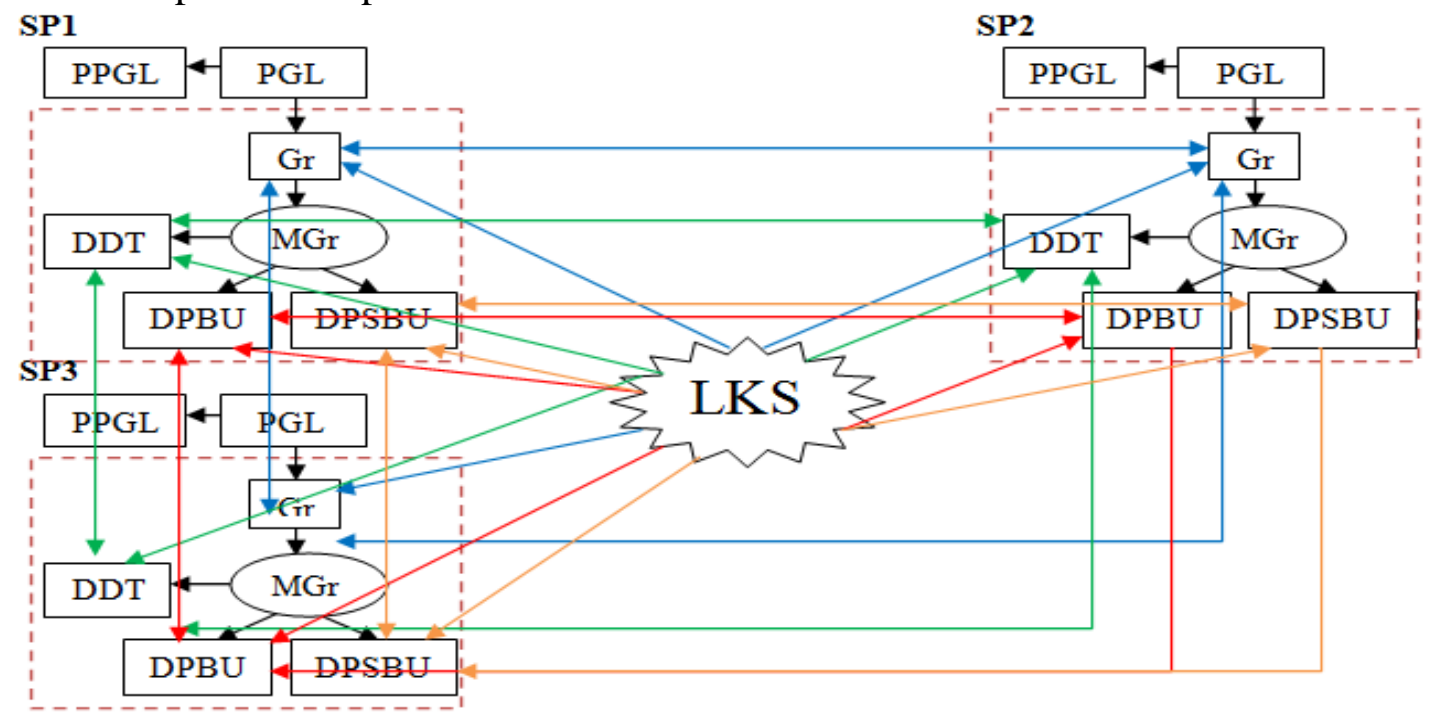

Gambar 2. Proses interaksi siswa perempuan saat diskusi kelompok berlangsung pada pertemuan kedua

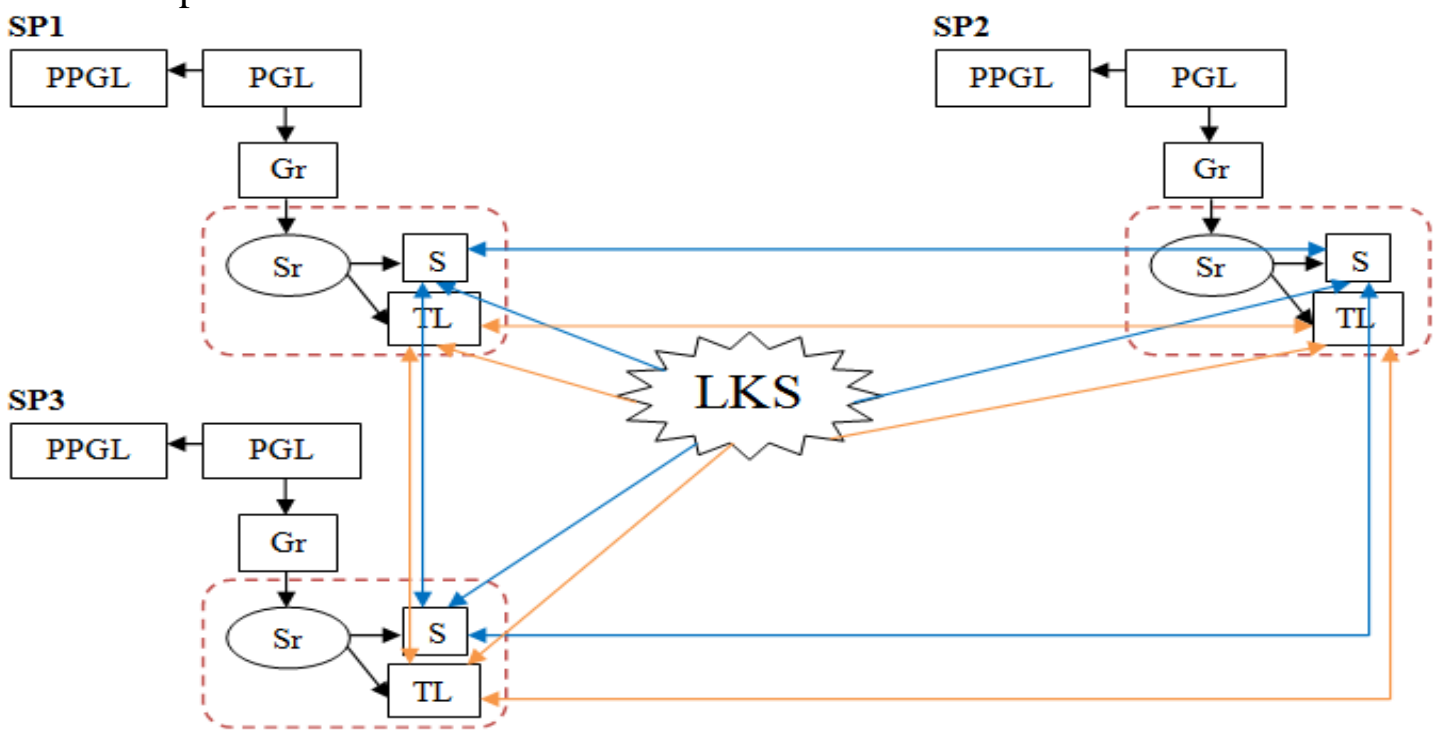

Gambar 3. Proses interaksi siswa perempuan saat diskusi kelompok berlangsung pada pertemuan ketiga 


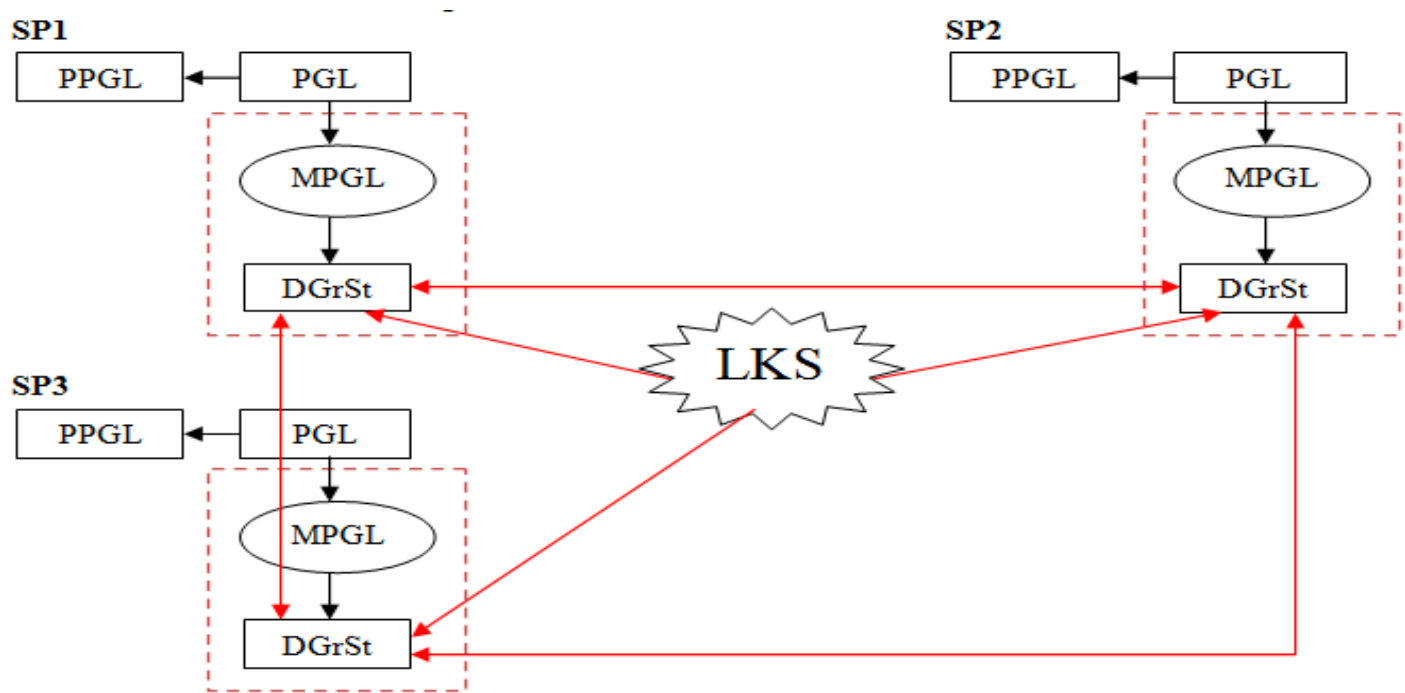

Gambar 4. Proses interaksi siswa perempuan saat diskusi kelompok berlangsung pada pertemuan ke empat

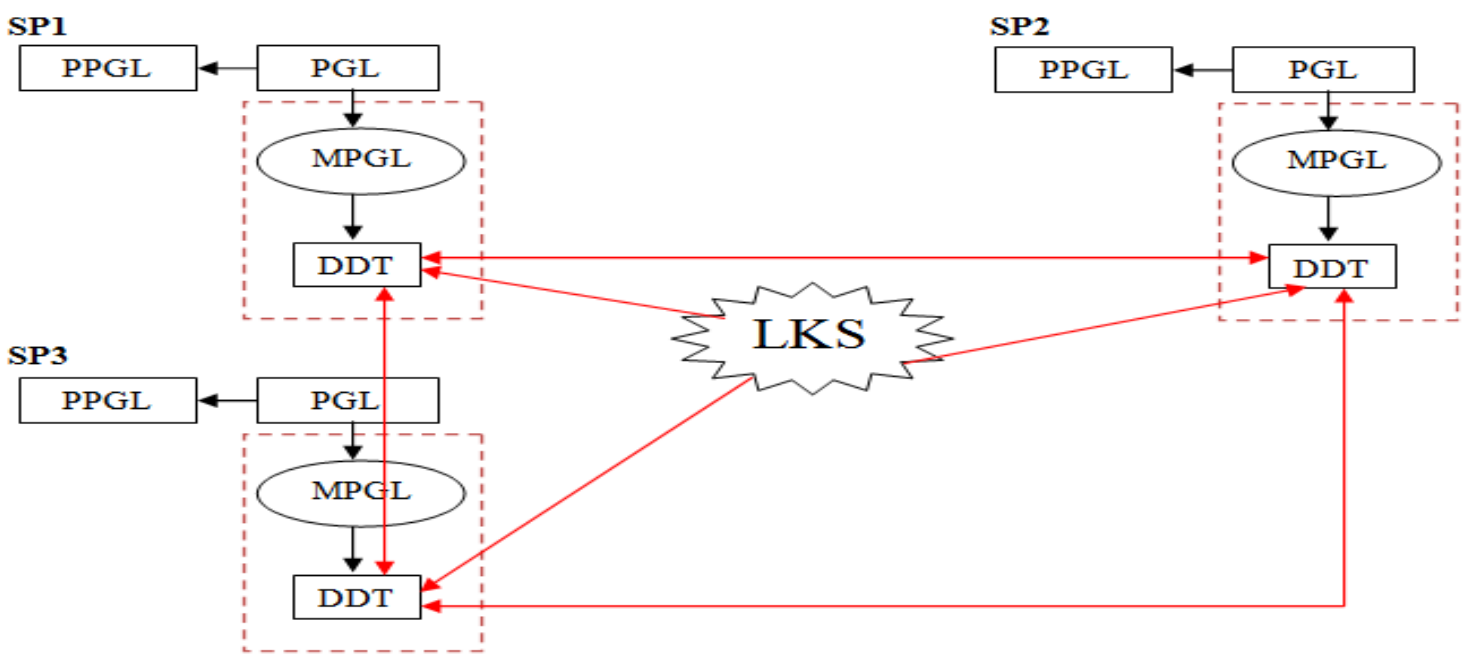

Gambar 5. Proses interaksi siswa perempuan saat diskusi kelompok berlangsung pada pertemuan ke lima

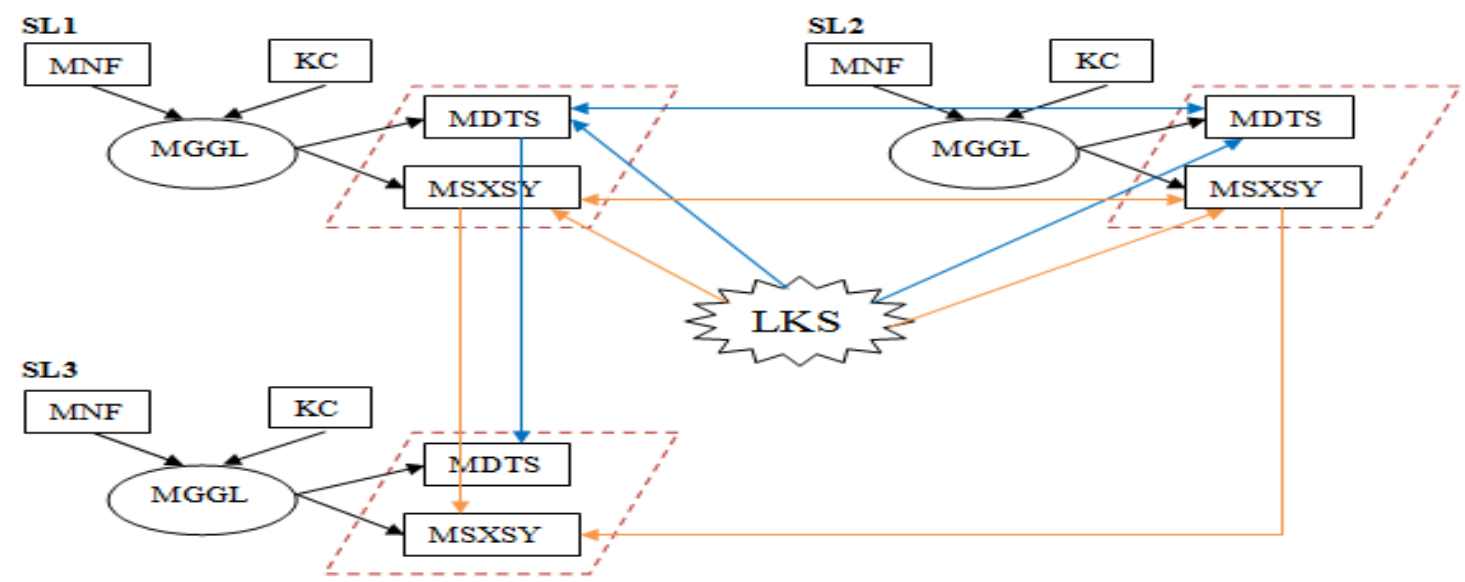

Gambar 6. Proses interaksi siswa laki-laki saat diskusi kelompok berlangsung pada pertemuan pertama 
SL1

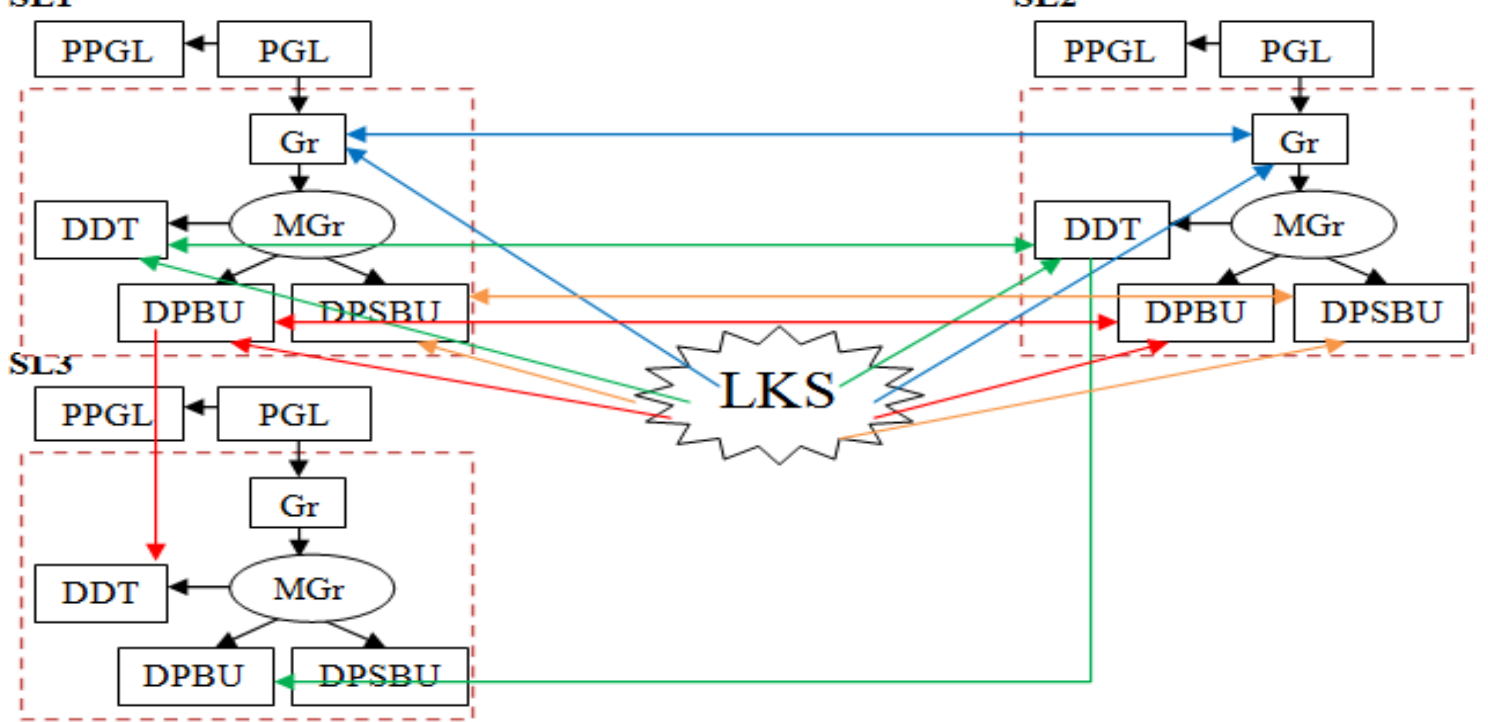

Gambar 7. Proses interaksi siswa laki-laki saat diskusi kelompok berlangsung pada pertemuan kedua

SL1

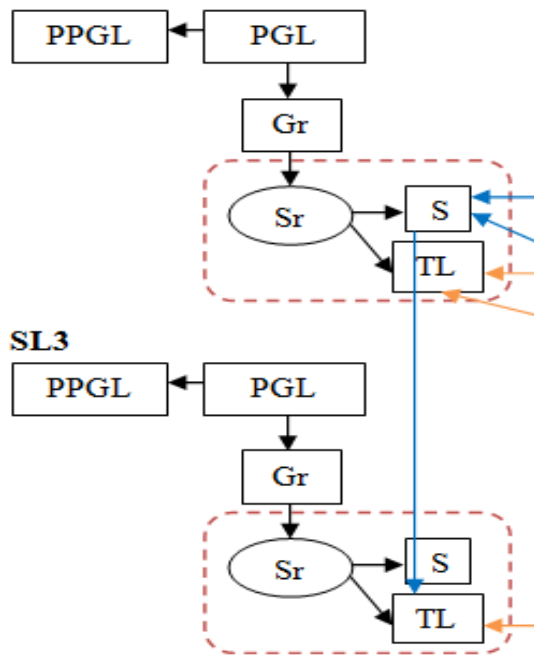

SL2

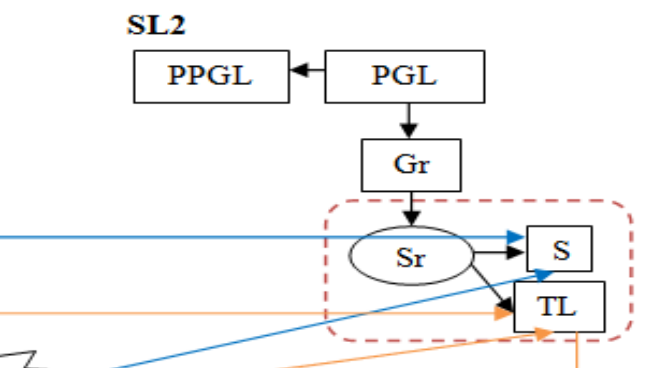

Gambar 8. Proses interaksi siswa laki-laki saat diskusi kelompok berlangsung pada pertemuan ketiga

SLI

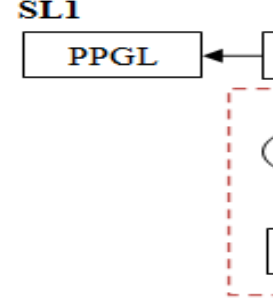

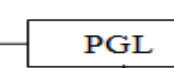

SL3

PPGL
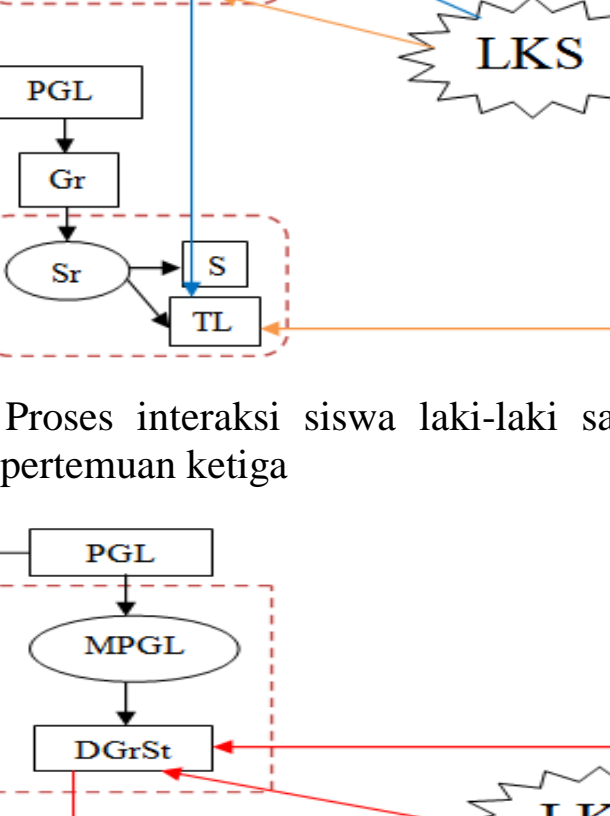


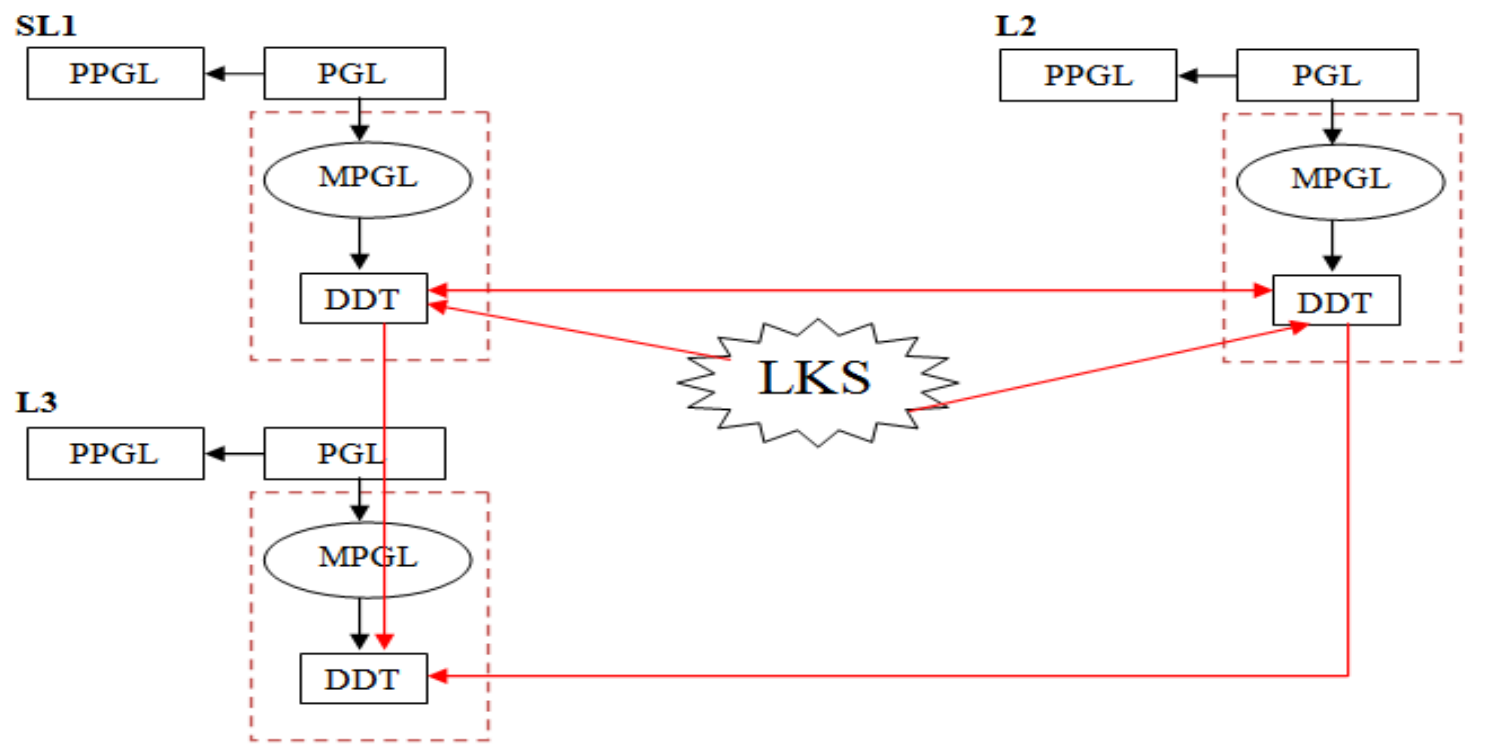

Gambar 10. Proses interaksi siswa laki-laki saat diskusi kelompok berlangsung pada pertemuan ke lima 